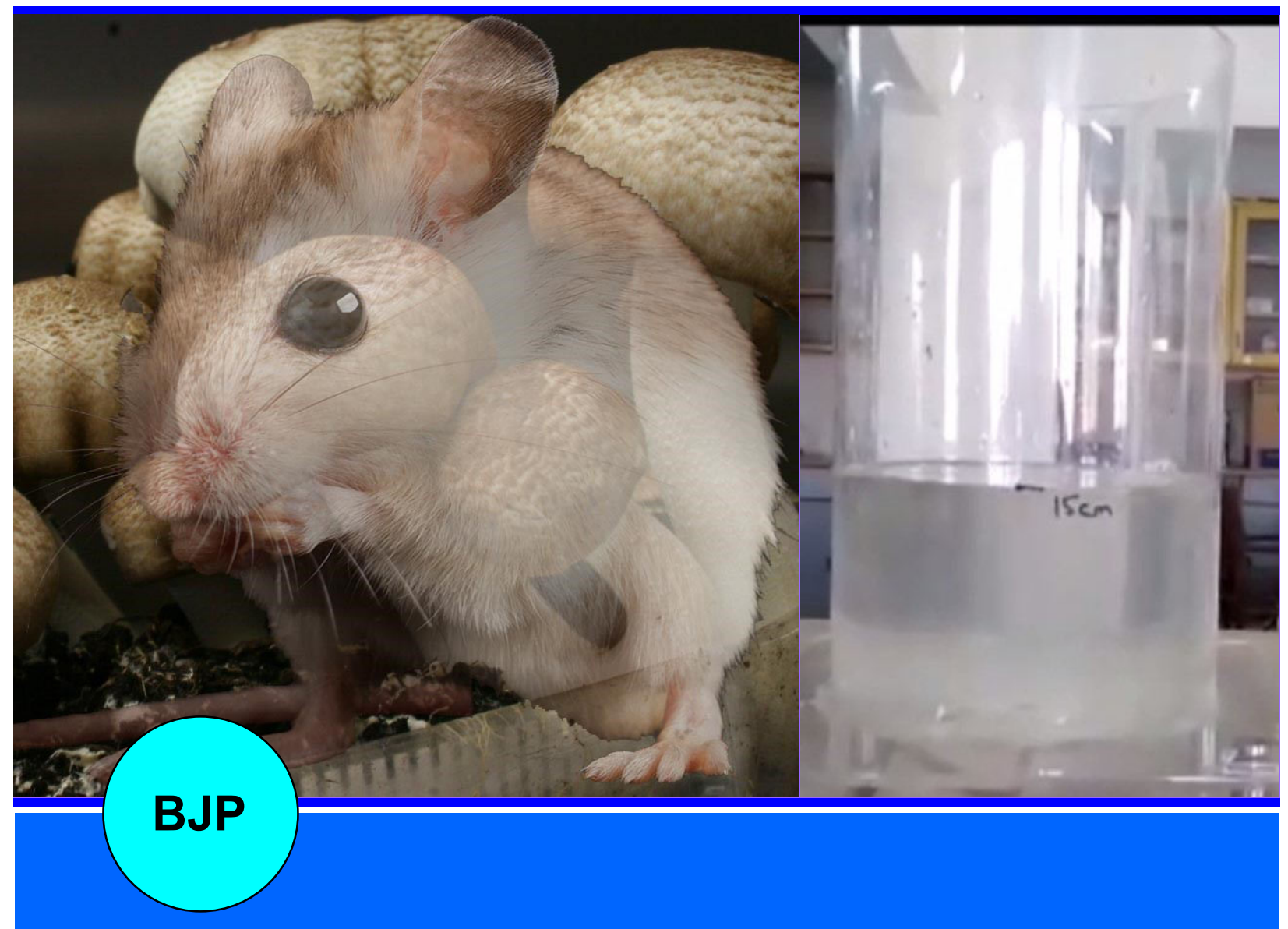

Bangladesh Journal of Pharmacology

Research Article

Antidepressant-like activity of hydroalcoholic extract of Agaricus blazei in stressed and unstressed mice 


\title{
Antidepressant-like activity of hydroalcoholic extract of Agaricus blazei in stressed and unstressed mice
}

\author{
Israr-ul-Haq1, Muhammad Aslam², Hammad Ahmed' and Nuzhat Sultana3 \\ ${ }^{1}$ Department of Pharmacology, Faculty of Pharmacy, Ziauddin University, Karachi, Pakistan; ${ }^{2}$ Department of \\ Pharmacology, Faculty of Pharmacy, University of Sindh, Jamshoro, Pakistan; 'Department of Pharmacology, \\ Faculty of Pharmacy, University of Karachi, Karachi, Pakistan.
}

\begin{tabular}{|c|c|}
\hline \multicolumn{2}{|l|}{ Article Info } \\
\hline Received: & 28 March 2019 \\
\hline Accepted: & 29 May 2019 \\
\hline Available Online: & 14 August 2019 \\
\hline \multicolumn{2}{|c|}{ DOI: 10.3329/bjp.v14i3.40803 } \\
\hline \multicolumn{2}{|c|}{$\begin{array}{l}\text { Cite this article: } \\
\text { Israr-ul-Haq, Aslam M, Ahmed H, } \\
\text { Sultana N. Antidepressant-like activi- } \\
\text { ty of hydroalcoholic extract of Agari- } \\
\text { cus blazei in stressed and unstressed } \\
\text { mice. Bangladesh J Pharmacol. 2019; } \\
\text { 14: 136-43. }\end{array}$} \\
\hline
\end{tabular}

\begin{abstract}
The aim of this study was to investigate the antidepressant activity of hydroalcoholic extract Agaricus blazei (273 and $819 \mathrm{mg} / \mathrm{kg}$; orally) in stressed and unstressed Swiss albino mice. Mice were immobilized to induce stress. Fluoxetine $20 \mathrm{mg} / \mathrm{kg}$ orally was given to stressed and unstressed animals and immobility time was noted by using forced swim test and tail suspension test. The concentration of plasma nitrite was also evaluated in stressed and unstressed mice. The effect of prazosin ( $\alpha_{1}$-adrenoceptor antagonist), p-CPA (parachlorophenylalanine-tryptophan hydroxylase inhibitor) and 7-nitroindazole (nNOS inhibitor) on the antidepressant activity of A. blazei was also evaluated. A. blazei and fluoxetine significantly decreased the duration of immobility time in stressed and unstressed mice, showing significant antidepressant activity. No substantial change was found in the locomotor activity. However, a significant reduction in the level of plasma nitrite was also noted in stressed mice. Hydroalcoholic extract showed prominent antidepressant activity in mice.
\end{abstract}

\section{Introduction}

Depression is a widespread disorder in almost all the communities of the world which renders the person unable to perform the routine functions of life associated with one's professional and social life.

In clinical practice, many classes of drugs are used as antidepressant drugs which include specific serotoninnorepinephrine reuptake inhibitors, tricyclic antidepressants, selective reversible inhibitors of monoamine oxidase A and selective serotonin reuptake inhibitors. But almost all these classes of drugs have numerous adverse drug reactions such as dizziness, confusion, insomnia, dry mouth, constipation, tachycardia, profuse sweating, weight changes and sexual dysfunction (Fajemiroye et al., 2016; Fava, 2003; Bet et al., 2013). This condition creates the need for the use of medicinal plants or plant-based medications for the treatment of depression.

St. John's wort, Hypericum perforatum, is a familiar plant for its clinical use to treat depression (Greeson et al., 2001). Other plants which possess antidepressant potential are Echium amoenum (Faryadian et al., 2014; Sayyah et al., 2006), C. satious (Shafiee et al., 201; Lopresti and Drummond, 2014), Lavandula spp. (Kageyama et al., 2012; Rahmati et al., 2017), grape seed (Rabiei et al., 2017); Hamelia patens (Surana and Wagh, 2017), Panax ginseng (Dang et al., 2009; Ge et al., 2017), Albizia julibrissin (Kim et al., 2007; Liu et al., 2015), Mentha pulegium (Rabiei et al., 2016), R. rosea (Saki et al., 2014; Mao, 2014).

A medicinal mushroom called Agaricus blazei Murrill is recognized by different names in different countries. At present, it is extensively used in oriental countries not only as a valuable food but also as a potential natural 
medicine in extract form (Giavasis, 2014). In this study, the antidepressant effect of the herb has been evaluated.

\section{Materials and Methods}

\section{Drugs and chemicals}

A. blazei extract was procured from ORIVeDA, ORIGO Holding BV, Amsterdam, The Netherlands. Fluoxetine was purchased from Hilton Pharma, Pakistan. Prazosin was bought from Pfizer, Pakistan. All other chemicals were purchased from Sigma-Aldrich, USA.

\section{Animals}

Male Swiss albino mice weighing 20-25 g and 3 months old were procured from the Karachi University. All the experimental mice were segregated into groups such that each polypropylene cage (approximately $29 \times 22 \times$ $14 \mathrm{~cm}$ ) contained 6 mice and were facilitated by alternate light and dark cycle of 12 hours at a room temperature of $\left(25-30^{\circ} \mathrm{C}\right)$. Free access to foodstuff and water were provided to the animals. However, food and water were not given to animals for 2 hours before and after the drug administration. Before conducting the experiments, an acclimatization period of 5 days was provided to animals.

\section{Selection of doses}

The dose selection of drugs and extract was done in accordance to the previous studies (Ni et al., 2013; Kwon et al., 2010; Binfaré et al., 2009; Rodrigues et al., 2002; Gilhotra et al., 2010).

\section{Animal groups}

Experimental design for assessing the antidepressantlike activity and nitrergic mechanism of $A$. blazei in unstressed and stressed mice using the tail suspension test: Group 1: Saline $10 \mathrm{~mL} / \mathrm{kg}$, p.o.; Group 2: Extract $273 \mathrm{mg} / \mathrm{kg}$, p.o.; Group 3: Extract $819 \mathrm{mg} / \mathrm{kg}$, p.o.; Group 4: fluoxetine $20 \mathrm{mg} / \mathrm{kg}$, p.o.; Group 5: saline 10 $\mathrm{mL} / \mathrm{kg}$, p.o.+ 7-nitroindazole $20 \mathrm{mg} / \mathrm{kg}$ i.p.; Group 6: Extract $819 \mathrm{mg} / \mathrm{kg}$, p.o.+7-nitroindazole $20 \mathrm{mg} / \mathrm{kg}$ i.p.; Group 7: saline $10 \mathrm{~mL} / \mathrm{kg}$, p.o. + stress; Group 8: Extract $273 \mathrm{mg} / \mathrm{kg}$, p.o. + stress; Group 9: Extract $819 \mathrm{mg} / \mathrm{kg}$, p.o.+ stress; Group 10: fluoxetine $20 \mathrm{mg} / \mathrm{kg}$, p.o. + stress; Group 11: saline $10 \mathrm{~mL} / \mathrm{kg}$, p.o. + aminoguanidine 50 $\mathrm{mg} / \mathrm{kg}$ i.p. + stress; Group 12: extract $819 \mathrm{mg} / \mathrm{kg}$, p.o.+ aminoguanidine $50 \mathrm{mg} / \mathrm{kg}$ i.p. + stress.

Experimental design for assessing the antidepressantlike activity and nitrergic mechanism of $A$. blazei in unstressed and stressed mice using forced swim test: Group 13: Saline $10 \mathrm{~mL} / \mathrm{kg}$, p.o.; Group 14: Extract 273 $\mathrm{mg} / \mathrm{kg}$, p.o.; Group 15: Extract $819 \mathrm{mg} / \mathrm{kg}$, p.o.; Group 16: Fluoxetine $20 \mathrm{mg} / \mathrm{kg}$, p.o.; Group 17: Saline $10 \mathrm{~mL} /$ $\mathrm{kg}$, p.o.+ 7-nitroindazole $20 \mathrm{mg} / \mathrm{kg}$ i.p.; Group 18: Extract $819 \mathrm{mg} / \mathrm{kg}$, p.o.+ 7-nitroindazole $20 \mathrm{mg} / \mathrm{kg}$ i.p.; Group 19: Saline $10 \mathrm{~mL} / \mathrm{kg}$, p.o.+ stress; Group 20:
Extract $273 \mathrm{mg} / \mathrm{kg}$, p.o.+ stress; Group 21: Extract 819 $\mathrm{mg} / \mathrm{kg}$, p.o.+ stress; Group 22: Fluoxetine $20 \mathrm{mg} / \mathrm{kg}$, p.o.+ stress; Group 23: Saline $10 \mathrm{~mL} / \mathrm{kg}$, p.o.+ aminoguanidine $50 \mathrm{mg} / \mathrm{kg}$ i.p.+ stress; Group 24: Extract 819 $\mathrm{mg} / \mathrm{kg}$, p.o.+ aminoguanidine $50 \mathrm{mg} / \mathrm{kg}$ i.p.+ stress.

Experimental design for assessing the monoaminergic mechanisms of the antidepressant-like activity of $A$. blazei in unstressed and stressed mice using tail suspension test. Group 25: Saline $10 \mathrm{~mL} / \mathrm{kg}$, p.o.+ sulpiride $50 \mathrm{mg} / \mathrm{kg}$ i.p.; Group 26: Extract $819 \mathrm{mg} / \mathrm{kg}$, p.o. + sulpiride $50 \mathrm{mg} / \mathrm{kg}$ i.p.; Group 27: Saline $10 \mathrm{~mL} /$ kg, p.o.+ prazosin $62.5 \mu \mathrm{g} / \mathrm{kg}$ i.p.; Group 28: Extract 819 $\mathrm{mg} / \mathrm{kg}$, p.o.+ prazosin $62.5 \mu \mathrm{g} / \mathrm{kg}$ i.p.; Group 29: Saline $10 \mathrm{~mL} / \mathrm{kg}$, p.o.+ p-CPA $100 \mathrm{mg} / \mathrm{kg}$ i.p.; Group 30: Extract $819 \mathrm{mg} / \mathrm{kg}$, p.o.+ p-CPA $100 \mathrm{mg} / \mathrm{kg}$ i.p.; Group 31: Saline $10 \mathrm{~mL} / \mathrm{kg}$, p.o.+ sulpiride $50 \mathrm{mg} / \mathrm{kg}$ i.p.+ stress; Group 32: Extract $819 \mathrm{mg} / \mathrm{kg}$, p.o.+ sulpiride 50 $\mathrm{mg} / \mathrm{kg}$ i.p.+ stress; Group 33: Saline $10 \mathrm{~mL} / \mathrm{kg}$, p.o.+ prazosin $62.5 \mu \mathrm{g} / \mathrm{kg}$ i.p.+ stress; Group 34: Extract 819 $\mathrm{mg} / \mathrm{kg}$, p.o.+ prazosin $62.5 \mu \mathrm{g} / \mathrm{kg}$ i.p.+ stress; Group 35: Saline $10 \mathrm{~mL} / \mathrm{kg}$, p.o.+ p-CPA $100 \mathrm{mg} / \mathrm{kg}$ i.p.+ stress; Group 36: Extract 819 mg/kg, p.o.+ p-CPA 100 mg/kg i.p.+ stress.

\section{Behavioral assessment}

\section{Induction of stress in mice}

For stress induction, the mice were subjected to immobilization from 11 am to 1:30 pm (150 min) by positioning their backs on a wooden board by means of tape to stick all four limbs and trunk (Sheikh et al., 2007). The drugs were given $45 \mathrm{~min}$ before immobilization. The behavioral study was performed after $10 \mathrm{~min}$ of recovering the animal from the immobilization (Gilhotra et al., 2010).

\section{Tail suspension test}

This is the most important test to determine the antidepressant activity in mice. Each mouse was suspended individually by its tail at a height of $50 \mathrm{~cm}$ above the floor of the table edge with the aid of adhesive tape at about $1 \mathrm{~cm}$ from the tip of the tail. Whereas, the animal was separated both visually and acoustically from each other during the test. Immobility time was noted manually with the help of stopwatch for $6 \mathrm{~min}$. If the animals did not exhibit any body movements, hung inertly and totally stationary, they were considered as immobile (da Silva et al., 2000).

\section{Open-field test}

For determination of the influence of A. blazei on locomotor activity, mice were assessed in the open-field model (TRU SCAN activity monitoring systems, Coulbourn Instruments) (Rodrigues et al., 1996). Individually the mice were placed in the center of the box (40 $\times 60 \times 50 \mathrm{~cm}$ ) to observe their behavior immediately and continues for $4 \mathrm{~min}$. The compulsory factors/ parameters including total activities, entire distance and 


\section{Box 1: Forced Swim Test}

Principle

The forced swim test (Porsolt test) is utilized for the evaluation of the antidepressant-like effects of the medication. The parameter noted in this test is called 'immobility', looking like a social condition of wretchedness, as found in human depression. In this test, mouse is compelled to swim in a limited space from which the mouse can't escape and is initiated to conduct of immobility. This conduct shows a condition of sadness which can be lessened with the use of antidepressant drug.

\section{Requirements}

Mouse, Stop watch, Swimming tank (transparent plexiglass, width $20 \mathrm{~cm}$, stature $30 \mathrm{~cm}$ ), Thermometer, Tissue roll

\section{Procedure}

Step 1: Fill the tank to the dimension of $15 \mathrm{~cm}$

Step 2: Change the water temperature to $25 \pm 1^{\circ} \mathrm{C}$ utilizing high temp water as well as ice to alter the temperature

Step 3: Note the temperature, utilizing a thermometer, before beginning the test

total ambulatory period were recorded with the help of a camera and protected in the computer (Liao et al., 2013).

\section{Biochemical assessment}

\section{Determination of plasma nitrite}

The plasma was obtained and centrifuged at $4^{\circ} \mathrm{C}$ for 10 min at 2,500 rpm. The plasma was refrigerated and then further processed for nitrite approximation within 24 hours (Dhingra and Bhankher, 2014). Spectrophotometric analysis based on Griess response was used for plasma nitrite estimation. In this reaction, plasma and Griess reagent were added in equal volume and incubated for $10 \mathrm{~min}$ at room temperature to obtain a chromophore. Spectrophotometer UV-VIS-NIR was used for the recorded absorbance at $543 \mathrm{~nm}$. A standard curve was created to calculate nitrite concentration consuming sodium nitrite as standard and expressing the concentration of nitrite in micromoles (Green et al., 1982).

\section{Statistical analysis}

The data are shown as the mean \pm standard error of the mean (SEM) with confidence intervals (CI) of 95\%. The data are interpreted by using one-way ANOVA following Tukey's post hoc test. A probability level of 0.05 or less is accepted as significant.

\section{Results}

The mouse subjected to immobility stress for $150 \mathrm{~min}$ showed a significant increase (from $166.6 \pm 4.4 \mathrm{sec}$ to $198.0 \pm 3.1 \mathrm{sec}$ using tail suspension test; $159.2 \pm 10.2 \mathrm{sec}$
Step 4: Delicately and gradually pick the animal by the tail and move it into the swimming tank

Step 5: Begin the clock effectively set at $6 \mathrm{~min}$

Step 6: After 6 min. expel the mouse from the swimming tank. Make it dry with a tissue, before exchanging it to its home cage.

\section{Notes}

Note down the mobility time for last $4 \mathrm{~min}(240 \mathrm{sec})$ of the total $6 \mathrm{~min}(360 \mathrm{sec})$ trial. Amid the underlying $2 \mathrm{~min}$ of total 6 min trial the mouse become incredibly active, vigorously, swim in circles, and endeavor to climb the divider or bounce to the base

Compute immobility time by subtracting portability time from the total time

Immobility $=240 \mathrm{sec}-$ Mobility

References

Abel and Bilitzke, 1990; Can et al., 2012; Porsolt et al., 1977; Yu et al., 2002

References for videos

Rabiei et al., 2017; Rabiei et al., 2016

to $200.4 \pm 13.1 \mathrm{sec}$ using forced swim test) in the immobility time. These suggested depression-like behavior. The immobility time in both unstressed and stressed mice was significantly decreased (from $166.6 \pm$ $4.4 \mathrm{sec}$ to $141.2 \pm 3.0 \mathrm{sec}$ in unstressed mice and $198.0 \pm$ $3.1 \mathrm{sec}$ to $148.0 \pm 3.1 \mathrm{sec}$ in stressed mice using tail suspension test) by treatment with $A$. blazei. The results showed that the extract possesses significant antidepressant activity. The immobility period of unstressed mice treated with 7-nitroindazole $(20 \mathrm{mg} / \mathrm{kg})$ decreased when compared with the vehicle-treated unstressed mice. Aminoguanidine also increased the antidepressant effect of the mice pretreated with A. blazei. However, 7-nitroindazole did not potentiate the effect of unstressed mice pretreated with the extract (Figure 1). In the forced swim test, $A$. blazei significantly decreased the immobility time in both unstressed and stressed mice (Figure 1).

Immobilized animals showed a significant decrease in locomotor activity. The locomotor activity was decreased to $287.6 \pm 9.6 \mathrm{sec}$ when compared with the vehicletreated group having the locomotor activity of $336.8 \pm$ 7.3 sec. However, A. blazei, aminoguanidine, 7-nitroindazole and the combinations of the drugs did not produce any effect on the locomotor activity of unstressed and stressed mice when compared to their respective control groups (Figure 1).

The immobility time was significantly increased in prazosin, sulpiride and p-CPA groups when compared to their respective control groups. The change in immobility time was $202.2 \pm 7.3 \mathrm{sec}$ increased to $212.2 \pm$ $4.9 \mathrm{sec}$ for prazosin, $188.4 \pm 4.9 \mathrm{sec}$ increased to $212.0 \pm$ $4.8 \mathrm{sec}$ for sulpiride and $190.4 \pm 7.7 \mathrm{sec}$ increased to 


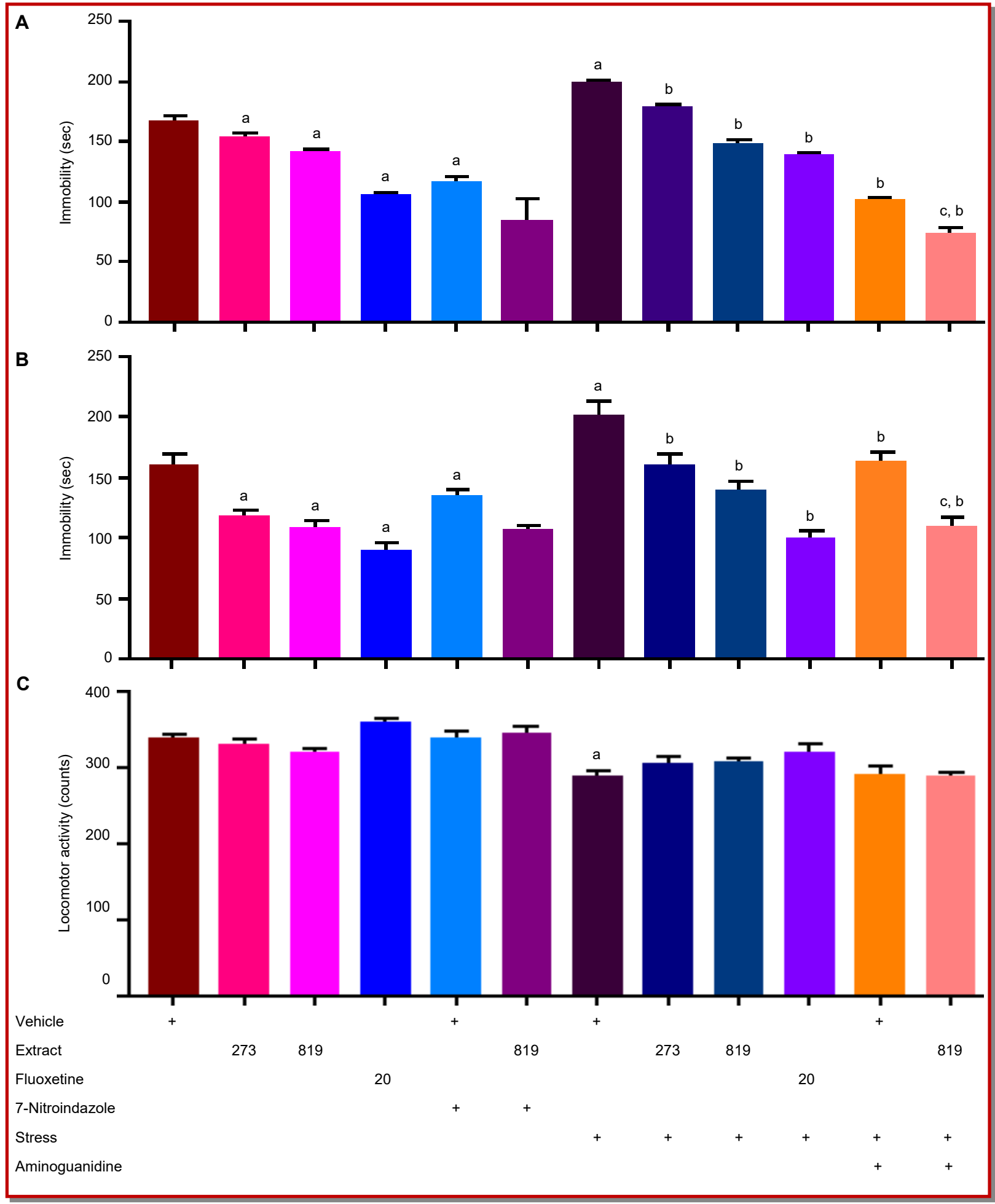

Figure 1: Effect of A. blazei and its combinations with 7-nitroindazole and aminoguanidine on immobility periods [using tail suspension test (A) and forced swim test (B)] and locomotor activity (C) of unstressed and stressed mice

$\mathrm{n}=6$ in each group; Values are expressed as the mean \pm SEM; Data were analyzed by one-way ANOVA followed by Tukey's test, except data for unstressed and stressed mice, which were analyzed by Student's unpaired t-test. ap $<0.05$, significant difference from vehicle-treated unstressed mice); $\mathrm{b} p<0.05$, significant difference from immobilization-induced stressed mice; $\mathrm{c} p<0.05$, significant difference from A. blazei (819 mg $/ \mathrm{kg})$-treated stressed mice; ${ }^{\mathrm{d}} \mathrm{p}<0.05$, significant difference from aminoguanidine-treated stressed mice 


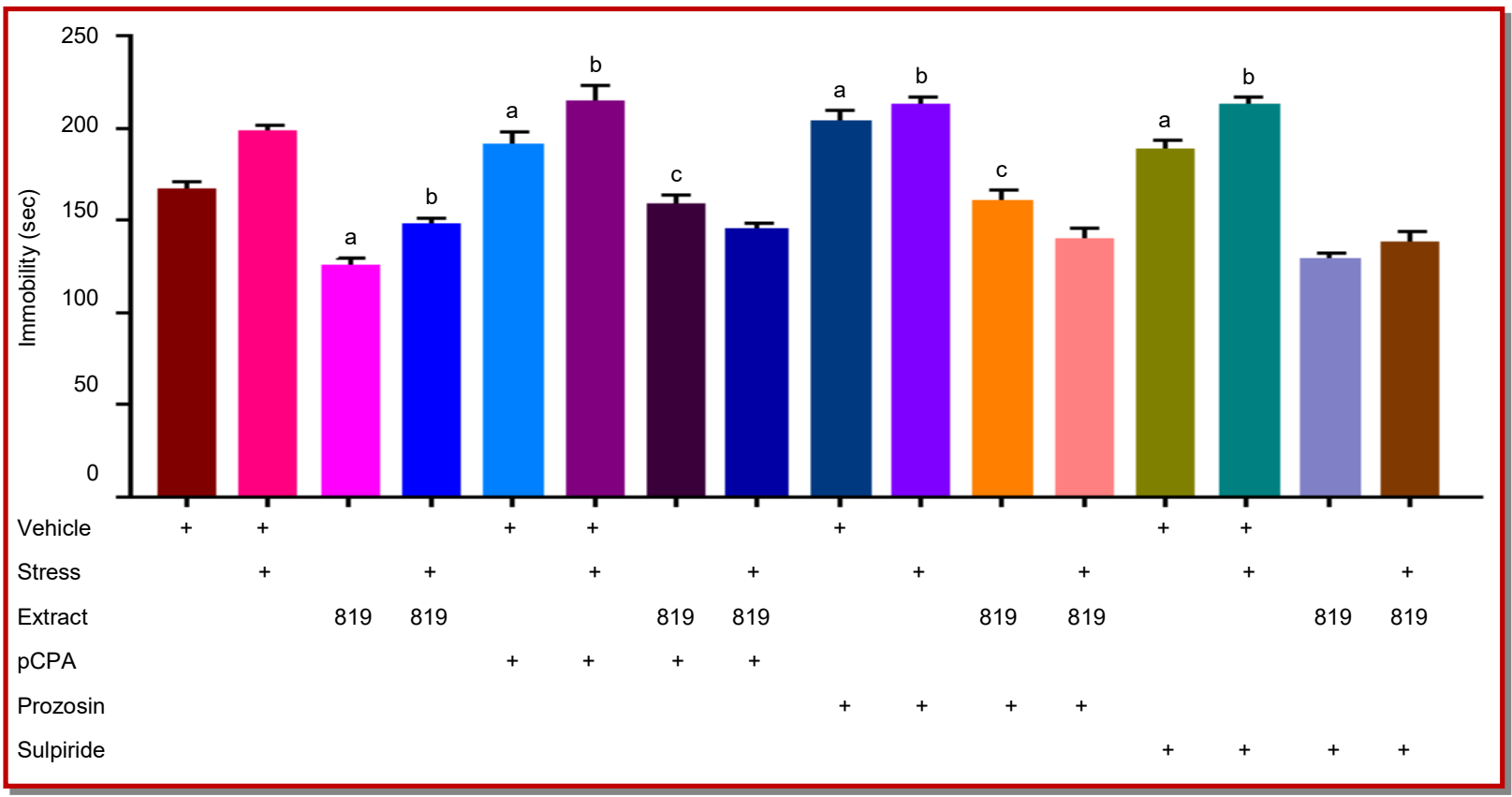

Figure 2: Effect of pCPA, prazosin and sulpiride per se and their combination with A. blazei on immobility periods of unstressed and stressed mice in TST.

$\mathrm{n}=6$ in each group. Values are expressed as the mean \pm SEM. Data were analyzed by one-way ANOVA followed by Tukey's test, except data for unstressed and stressed mice, which were analysed by Student's unpaired t-test. ${ }^{a} \mathrm{p}<0.05$, significant difference from vehicle-treated unstressed mice); ${ }^{b} p<0.05$, significant difference from immobilization-induced stressed mice; ${ }^{c} p<0.05$, significant difference from A. blazei (819 mg/kg)-treated stressed mice; ${ }^{\mathrm{d}}<0.05$, significant difference from aminoguanidine-treated stressed mice

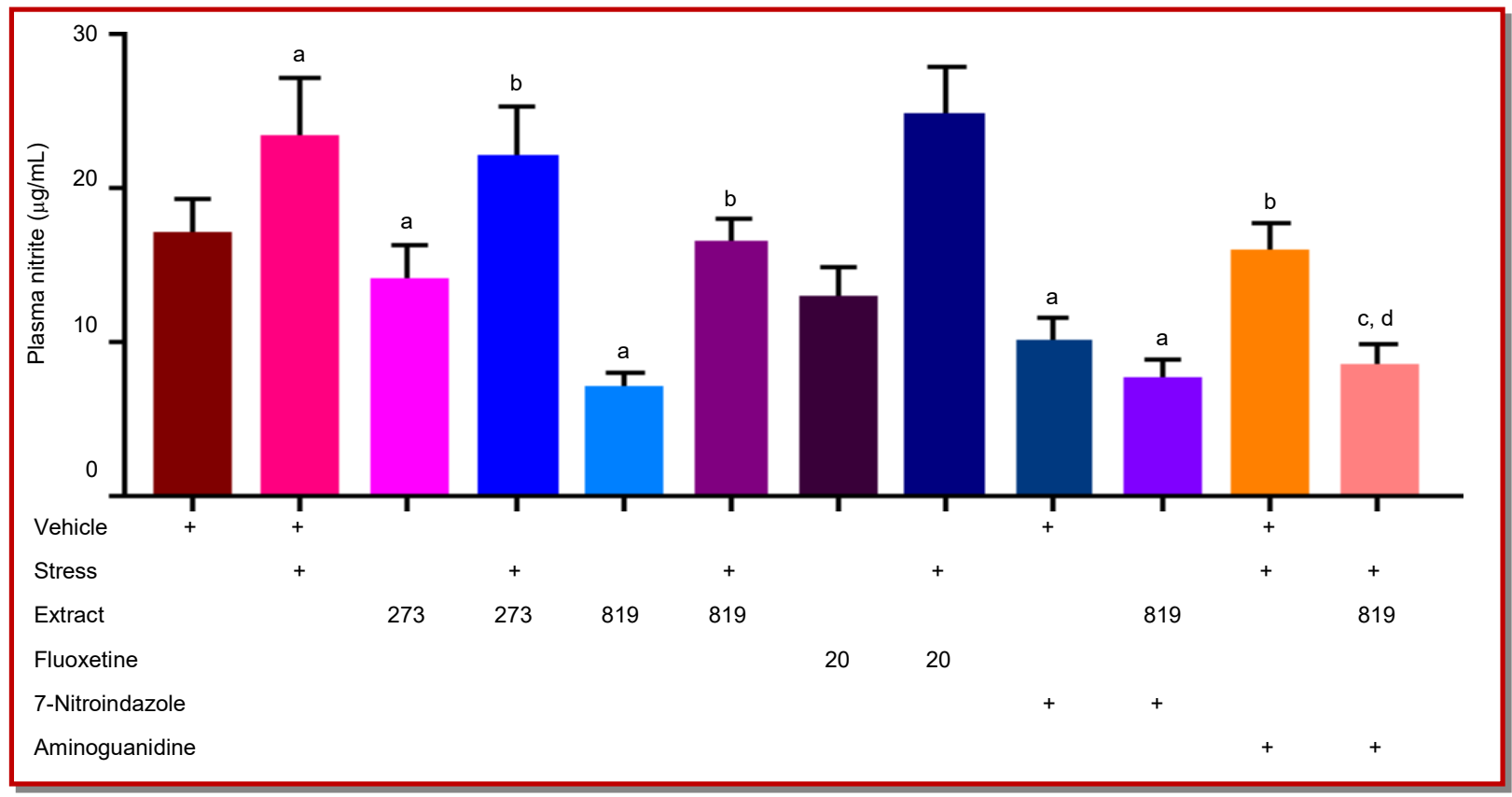

Figure 3: Effect of A. blazei and its combinations with 7-nitroindazole and aminoguanidine on plasma nitrite levels of unstressed and stressed mice.

$\mathrm{n}=6$ in each group. Values are expressed as the mean \pm SEM. Data were analyzed by one-way ANOVA followed by Tukey's test, except data for unstressed and stressed mice, which were analysed by Student's unpaired t-test. ap $<0.05$, significant difference from vehicle-treated unstressed mice); ${ }^{\mathrm{b}} \mathrm{p}<0.05$, significant difference from immobilization-induced stressed mice; ${ }^{c} \mathrm{p}<0.05$, significant difference from A. blazei $(819 \mathrm{mg} / \mathrm{kg})$-treated stressed mice; ${ }^{\mathrm{p}}<0.05$, significant difference from aminoguanidine-treated stressed mice 
$213.6 \pm 9.7 \mathrm{sec}$ for $\mathrm{p}-\mathrm{CPA}$.

However, pretreatment of the mice with prazosin and $p$ -CPA reversed the decrease in immobility time produced by A. blazei. The change in immobility time was $148.0 \pm 3.1 \mathrm{sec}$ increased to $160.4 \pm 6.4 \mathrm{sec}$ by prazosin and $148.0 \pm 3.1 \mathrm{sec}$ increased to $158.6 \pm 5.3 \mathrm{sec}$ by $\mathrm{p}-\mathrm{CPA}$ (Figure 2).

The plasma nitrite levels of stressed mice were elevated to $23.2 \pm 3.9 \mu \mathrm{g} / \mathrm{mL}$ when compared with the vehicletreated unstressed mice having the levels of $17.0 \pm 2.2$ $\mu \mathrm{g} / \mathrm{mL}$. The plasma nitrite levels of the stressed mice treated with the extract at the dose of $273 \mathrm{mg} / \mathrm{kg}$ and $819 \mathrm{mg} / \mathrm{kg}$ were significantly reduced to $14.0 \pm 2.2 \mu \mathrm{g} /$ $\mathrm{mL}$ and $7.0 \pm 0.9 \mu \mathrm{g} / \mathrm{mL}$ respectively. There was also a significant decrease in the plasma nitrite levels in 7nitroindazole and aminoguanidine groups. The change in plasma nitrite levels was $10.0 \pm 1.5 \mu \mathrm{g} / \mathrm{mL}$ for 7 nitroindazole group and $15.8 \pm 1.9 \mu \mathrm{g} / \mathrm{mL}$ for aminoguanidine group when compared to vehicle-treated control group having the levels of $23.2 \pm 3.9 \mu \mathrm{g} / \mathrm{mL}$.

The results also show that the plasma nitrite decreasing effect of the extract was significantly potentiated by aminoguanidine in stressed mice to the levels of $8.4 \pm$ $1.4 \mu \mathrm{g} / \mathrm{mL}$. However, 7-nitroindazole did not potentiate the plasma nitrite decreasing effect of the extract (Figure 3).

\section{Discussion}

The present study has demonstrated that A. blazei (273 $\mathrm{mg} / \mathrm{kg}$ and $819 \mathrm{mg} / \mathrm{kg}$, p.o) possesses the antidepressant-like effect in unstressed and stressed mice. This effect was assessed by utilizing the forced swim test and tail suspension test. These models are comprehensively used in rodents to foresee antidepressant-like potential by assessing the decrease in immobility time (Rodrigues et al., 2002)

Among the two doses of the extract, the dose of 819 $\mathrm{mg} / \mathrm{kg}$. p.o. showed the highest antidepressant-like activity in unstressed and stressed mice, so this dose of A. blazei was used to evaluate the mechanism of antidepressant activity. According to amine hypothesis, the depression is caused by the decreased concentration of serotonin (5-HT) and/or noradrenaline (NA) in the brain. This speculation is bolstered by the way that the depression is mitigated using the drugs that elevate the levels of amine neurotransmitters (Krishnan and Nestler, 2008). Practically all antidepressant medications act upon one or more of the following mechanisms to give their effect: hindrance of 5-HT reuptake or NA (and DA), restraint of monoamine oxidase or threat of inhibitory preganglionic NA or 5-HT receptors. These components result in the expanded neurotransmission of NA and additionally 5-HT. The findings of this study show that the antidepressant-like effect of A. blazei in unstressed mice was reversed by pretreatment with prazosin and p-CPA. As p-CPA is a serotonin synthesis inhibitor so for serotonin deletion $\mathrm{p}$-CPA was given for four consecutive days (Binfaré et al., 2009). Thus, A. blazei $(819 \mathrm{mg} / \mathrm{kg})$ might produce significant antidepressant-like activity in unstressed mice by interaction with the serotonergic receptor and $a_{1}$-adrenoceptors, hence elevating the serotonin and norepinephrine levels. The level of monoamines like serotonin and norepinephrine decreased in depression, so drugs like monoamine oxidase (MAO) inhibitors and tricyclic antidepressants (TCAs) which increase the level of these monoamines are used to treat depression (Porsolt et al., 1977). 7-nitroindazole, neuronal nitric oxide synthase (nNOS), the inhibitor has been investigated to have antidepressant-like activity in unstressed mice (Tsuchiya et al., 1977). When 7-nitroindazole was administered to unstressed mice, which were already treated with the extract $(819 \mathrm{mg} / \mathrm{kg})$, there was no significant reduction in the immobility time when compared with A. blazei and 7-nitroindazole per se, suggesting that the antidepressant activity of $A$. blazei is not through nNOS inhibition.

Significantly reduced plasma nitrite levels were observed in unstressed mice administered 7-nitroindazole individually when compared with the vehicle control group. Although it did not enhance the plasma nitrite, however the decreasing effect of the extract in unstressed mice when compared to A. blazei and 7nitroindazole per se which strongly supports that the antidepressant-like activity of $A$. blazei is not due to the association of nNOS. Whereas, the antidepressant activity of $A$. blazei was not significantly reversed in stressed mice that were already treated with p-CPA, prazosin, or sulpiride which indicates that the antidepressant-like activity of $A$. blazei is not through the interaction of the monoaminergic system so, in stressed mice, there might be some other mechanisms involved in the antidepressant-like activity of A. blazei. Acute restraint stress in rodents significantly elevates expression of inducible NOS (Tsuchiya et al., 1977). Aminoguanidine, inducible nitric oxide synthase (iNOS) inhibitor administration to stressed mice pretreated with $A$. blazei, the immobility time was significantly decreased as compared to A. blazei and aminoguanidine per se, suggesting that the antidepressant-like activity of $A$. blazei might be through the inhibition of iNOS. The plasma nitrite levels were significantly decreased in stressed mice treated with $\mathrm{ABM}$ and aminoguanidine. This further supports that the antidepressant-like activity of A. blazei in stressed mice is due to iNOS.

The restraint stress decreases superoxide dismutase and catalase levels and increased lipid peroxidation (Kashif et al., 2003). It has been investigated through a series of studies that there exists a correlation between depre- 
ssive disorders and oxidative stress, either in the blood or brain (Bilici et al., 2001; Michel et al., 2007). Further, it was known that the activities of antioxidant enzymes are decreased in patients diagnosed with major depressive disorder, while this effect is ameliorated with the use of antidepressants (Herken et al., 2007).

Many studies have demonstrated that plants having antioxidant activities have shown antidepressant-like effects in rodents (Singh et al., 2009; Prakash et al., 2018). A. blazei has proven itself as an excellent antioxidant herb (Hakime-Silva et al., 2013) this antioxidant potential of the herb might have played a role in the antidepressant-like activity of this magic mushroom. Furthermore, no significant change was observed in the locomotor function of stressed and unstressed mice with respect to their vehicle control groups, so it showed that A. blazei has no effect on locomotor activity. This observation highly supports our hypothesis that the antidepressant-like activity of A. blazei is specific and not a false positive.

\section{Conclusion}

The antidepressant-like activity of A. blazei in unstressed mice is probably through interaction with adrenergic and serotonergic systems, while the antidepressant-like activity of $A$. blazei in stressed mice is probably through inducible NOS inhibition and its anti-oxidant activity.

\section{Ethical Issue}

The animals were handled according to the requirements mentioned in "Guidelines for the care and use of laboratory animals $8^{\text {th }}$ edition" (Garber et al., 2011).

\section{Conflict of Interest}

The authors have no conflict of interest.

\section{Acknowledgement}

We are very thankful to Prof. Ali Akbar Sial for his scholarly suggestions during the design of this study.

\section{References}

Berton O, Nestler EJ. New approaches to antidepressant drug discovery: Beyond monoamines. Nat Rev Neurosci. 2006; 7: 137-57.

Bet PM, Hugtenburg JG, Penninx BW, Hoogendijk WJ. Side effects of antidepressants during long-term use in a naturalistic setting. Eur Neuropsychopharmacol. 2013; 23: 1443-51.

Bilici M, Efe H, Köroğlu MA, Uydu HA, Bekaroğlu M, Değer
O. Antioxidative enzyme activities and lipid peroxidation in major depression: Alterations by antidepressant treatments. J Affect Disord. 2001; 64: 43-51.

Binfaré RW, Rosa AO, Lobato KR, Santos AR, Rodrigues AL. Ascorbic acid administration produces an antidepressantlike effect: Evidence for the involvement of monoaminergic neurotransmission. Prog Neuropsychopharmacol Biol Psychiatry. 2009; 33: 530-40.

Can A, Dao DT, Terrillion CE, Piantadosi SC, Bhat S, Gould TD. The tail suspension test. J Vis Exp. 2012; 59, e3769.

Dang H, Chen Y, Liu X, Wang Q, Wang L, Jia W. Antidepressant effects of ginseng total saponins in the forced swimming test and chronic mild stress models of depression. Prog Neuropsychopharmacol Biol Psychiatry. 2009; 33: 141724

da Silva GD, Matteussi AS, dos Santos ARS, Calixto JB, Rodrigues AL. Evidence for dual effects of nitric oxide in the forced swimming test and in the tail suspension test in mice. Neuroreport 2000; 11: 3699-702.

Dhingra D, Bhankher A. Behavioral and biochemical evidences for antidepressant-like activity of palmatine in mice subjected to chronic unpredictable mild stress. Pharmacol Rep. 2014; 66: 1-9.

Dhingra D, Joshi P, Gupta A, Chhillar R. Possible involvement of monoaminergic neurotransmission in antidepressant-like activity of Emblica officinalis fruits in mice. CNS Neurosci Ther. 2012; 18: 419-25.

Fajemiroye J, da Silva D, de Oliveira D, Costa E. Treatment of anxiety and depression: Medicinal plants in retrospect. Fundam Clin Pharmacol. 2016; 30: 198-215.

Faryadian S, Sydmohammadi A, Khosravi A, Kashiri M, Faryadayn P, Abasi N. Aqueous extract of Echium amoenum elevate CSF serotonin and dopamine level in depression rat. Biomed Pharmacol J. 2014; 7: 137-42

Fava M. Diagnosis and definition of treatment-resistant depression. Biol Psychiatry. 2003; 5: 649-59.

Garber J, Barbee W, Bielitzki J, Clayton L, Donovan J, Kohn D, Lipman N, Locke P, Melcher J, Quimby F, Turner P, Wood G, Würbel H. Guidelines for care and use of laboratory animals. 8th ed. Washington, The National Academies Press, 2011.

Ge W, Li H, Zhao Y, Cai E, Zhu H, Gao Y. Study on antidepressant activity of sesquiterpenoids from ginseng root. J Funct Foods. 2017; 33: 261-67.

Giavasis I. Bioactive fungal polysaccharides as potential functional ingredients in food and nutraceuticals. Curr Opin Biotechnol. 2014; 26: 162-73.

Gilhotra N, Jain H, Dhingra D. Differential effects of nitric oxide synthase inhibitors on anxiety in unstressed and stressed mice. Indian J Exp Biol. 2010; 48: 365-72.

Green LC, Wagner DA, Glogowski J, Skipper PL, Wishnok JS, Tannenbaum SR. Analysis of nitrate, nitrite, and [15N] nitrate in biological fluids. Anal Biochem. 1982; 126: 131-38.

Greeson J, Sanford B, Monti D. St. John's wort (Hypericum perforatum): A review of the current pharmacological, toxicological, and clinical literature. Psychopharmacology 2001; 153: 402-14.

Hakime-Silva RA, Vellosa JC, Khalil NM, Khalil OA, Brunetti 
IL, Oliveira OM. Chemical, enzymatic and cellular antioxidant activity studies of Agaricus blazei Murrill. An Acad Bras Cienc. 2013; 85: 1073-82.

Herken H, Gurel A, Selek S, Armutcu F, Ozen ME, Bulut M, Kap O, Yumru M, Savas HA, Akyol O. Adenosine deaminase, nitric oxide, superoxide dismutase, and xanthine oxidase in patients with major depression: Impact of antidepressant treatment. Arch Med Res. 2007; 38: 247-52.

Kageyama A, Ueno T, Oshio M, Masuda $H$, Horiuchi $H$, Yokogoshi H. Antidepressant-like effects of an aqueous extract of lavender (Lavandula angustifolia Mill.) in rats. Food Sci Tech Res. 2012; 18: 473-79.

Kashif SM, Zaidi R, Al-Qirim TM, Hoda N, Banu N. Modulation of restraint stress induced oxidative changes in rats by antioxidant vitamins. J Nutr Biochem. 2003; 14: 633-36.

Kim J, Kim S, Lee S, Jang C. Antidepressant-like effects of Albizzia julibrissin in mice: Involvement of the 5-HT1A receptor system. Pharmacol Biochem Behav. 2007; 87: 41-47.

Krishnan V, Nestler E. The molecular neurobiology of depression. Nature 2008; 455: 894-902.

Kwon S, Lee B, Kim M, Lee H, Park HJ, Hahm DH. Antidepressant-like effect of the methanolic extract from Bupleurum falcatum in the tail suspension test. Prog Neuropsychopharmacol Biol Psychiatry. 2010; 34: 265-70.

Liao JC, Tsai JC, Liu CY, Huang HC, Wu LY, Peng WH. Antidepressant-like activity of turmerone in behavioral despair tests in mice. BMC Complement Altern Med. 2013; 13: 299.

Liu L, Liu C, Wang Y, Wang P, Li Y, Li B. Herbal medicine for anxiety, depression and insomnia. Curr Neuropharmacol. 2015; 13: 481-93.

Lopresti A, Drummond P. Saffron (Crocus sativus) for depression: A systematic review of clinical studies and examination of underlying antidepressant mechanisms of action. Human Psychopharmacol Clin Exp. 2014; 29: 517-27.

Mao J. Rhodiola Rosea therapy for major depressive disorder: A study protocol for a randomized, double-blind, placebocontrolled trial. J Clin Trials. 2014; 4: 1-15.

Michel TM, Frangou S, Thiemeyer D, Camara S, Jecel J, Nara K, Brunklaus A, Zoechling R, Riederer P. Evidence for oxidative stress in the frontal cortex in patients with recurrent depressive disorder: A postmortem study. Psychiatry Res. 2007; 151: 145-50.

Moussavi S, Chatterji S, Verdes E, Tandon A, Patel V, Ustun B. Depression, chronic diseases, and decrements in health: Results from the World Health Surveys. Lancet 2007; 370: 851-58.

Murray CJ, Lopez AD. The global burden of disease, 19902020. Nat Med. 1998; 4: 1241-43.

Ni WY, Wu MF, Liao NC, Yeh MY, Lu HF, Hsueh SC, Liu JY, Huang $\mathrm{YP}$, Chang $\mathrm{CH}$, Chung JG. Extract of medicinal mushroom Agaricus blazei Murill enhances the non-specific and adaptive immune activities in BALB/c mice. In vivo. 2013; 27: 779-86.

Porsolt RD, Bertin A, Jalfre M. Behavioral despair in mice: A primary screening test for antidepressants. Archives Internationales de Pharmacodynamie et de therapie. 1977; 229: 32736.
Prakash B. Screening of antioxidant and antidepressant activity of Vanda tessellata leaves extract. Int J Green Pharm. 2018; 12.

Rabiei Z, Gholami M, Rafieian-Kopaei M. Antidepressant effects of Mentha pulegium in mice. Bangladesh J Pharmacol. 2016; 11: 711-15.

Rabiei Z, Naderi S, Rafieian-Kopaei M. Study of antidepressant effects of grape seed oil in male mice using tail suspension and forced swim tests. Bangladesh J Pharmacol. 2017; 12: 397 -402 .

Rahmati B, Kiasalari Z, Roghani M, Khalili M, Ansari F. Antidepressant and anxiolytic activity of Lavandula officinalis aerial parts hydroalcoholic extract in scopolamine-treated rats. Pharm Biol. 2017; 55: 958-65.

Rodrigues AL, Rocha JB, Mello CF, Souza DO. Effect of perinatal lead exposure on rat behaviour in open-field and two-wky avoidance tasks. Pharmacol Toxicol. 1996; 79: 15056.

Saki K, Bahmani M, Rafieian-Kopaei M. The effect of most important medicinal plants on two important psychiatric disorders (anxiety and depression): A review. Asian Pac J Trop Med. 2014; 7: S34-S42.

Sayyah M, Sayyah M, Kamalinejad M. A preliminary randomized double-blind clinical trial on the efficacy of aqueous extract of Echium amoenum in the treatment of mild to moderate major depression. Prog Neuropsychopharmacol Biol Psychiatry. 2006; 30: 166-69.

Shafiee M, Arekhi S, Omranzadeh A, Sahebkar A. Saffron in the treatment of depression, anxiety and other mental disorders: Current evidence and potential mechanisms of action. J Affect Disord. 2018; 227: 330-37.

Sheikh N, Ahmad A, Siripurapu KB, Kuchibhotla VK, Singh S, Palit G. Effect of Bacopa monniera on stress induced changes in plasma corticosterone and brain monoamines in rats. J Ethnopharmacol. 2007; 111: 671-76.

Singh G, Garabadu D, Muruganandam A, Joshi V, Krishnamurthy S. Antidepressant activity of Asparagus racemosus in rodent models. Pharmacol Biochem Behav. 2009; 91: 283-90.

Surana A, Wagh R. GC-MS profiling and antidepressant-like effect of the extracts of Hamelia patens in animal model. Bangladesh J Pharmacol. 2017; 12: 410-16.

Tsuchiya T, Kishimoto J, Koyama J, Ozawa T. Modulatory effect of 1-NAME, a specific nitric oxide synthase (NOS) inhibitor, on stress-induced changes in plasma adrenocorticotropic hormone (ACTH) and corticosterone levels in rats: Physiological significance of stress-induced NOS activation in hypothalamic-pituitary-adrenal axis. Brain Res. 1997; 776: 68-74.

Yi LT, Xu HL, Feng J, Zhan X, Zhou LP, Cui CC. Involvement of monoaminergic systems in the antidepressant-like effect of nobiletin. Physiol Behav. 2011; 102: 1-6.

\section{Author Info}

I Muhammad Aslam (Principal contact)

, e-mail: pharmacologist1@yahoo.com 